\title{
Relationship between the abundance of the Endangered volcano rabbit Romerolagus diazi and vegetation structure in the Sierra Chichinautzin mountain range, Mexico
}

\author{
Areli Rizo-Aguilar, José Antonio Guerrero, Mircea G. Hidalgo-Minart \\ and Alberto GonzÁlez-Romero
}

\begin{abstract}
The volcano rabbit Romerolagus diazi is endemic to the mountains of central Mexico, where its habitat has been gradually destroyed to make way for agriculture, ranching and logging, and by forest fires. The volcano rabbit is categorized as Endangered on the IUCN Red List. We evaluated the relationship between the abundance of the volcano rabbit and vegetation structure at a small scale ( $0.25 \mathrm{ha}$ ). Using a general linear model we generated a set of 21 predictive models and proposed the best model as a habitat quality index. Our results suggest that greater height and cover of bunchgrasses and the presence of a shrub layer offer the volcano rabbit the best refuge from predators. The habitat quality index and the limited available habitat documented in our survey indicate that the populations of volcano rabbits in the study area are more threatened than previously thought. As $R$. diazi is a habitat specialist it does not have the option of moving to another habitat type.
\end{abstract}

Keywords Endemic, habitat quality index, habitat specialist, lagomorph, Mexico, pellet count, Romerolagus diazi, volcano rabbit

\section{Introduction}

The volcano rabbit Romerolagus diazi is endemic to mountains and the Popocatépetl, Iztaccíhuatl, Pelado and Tláloc volcanoes. Known locally as the teporingo or zacatuche, the species is distributed over c. $386 \mathrm{~km}^{2}$ (Velázquez et al., 1996) at elevations of 2,800-4,250 m (Fa \& Bell, 1990). The volcano rabbit is considered a habitat specialist and depends on wild subalpine bunchgrass

\footnotetext{
Areli Rizo-Aguilar (Corresponding author) and Alberto GonZÁleZ-Romero Instituto de Ecología, A. C., Carretera antigua a Coatepec No 351, El Haya, C.P. 91070, Xalapa, Veracruz, Mexico. E-mail areli_rizo@yahoo.com.mx

José Antonio Guerrero Facultad de Ciencias Biológicas, Universidad Autónoma del Estado de Morelos, Cuernavaca, Mexico

Mircea G. Hidalgo-Mihart División Académica de Ciencias Biológicas, Universidad Juárez Autónoma de Tabasco, Villahermosa, Mexico

Received 15 June 2012. Revision requested 31 October 2012.

Accepted 18 June 2013. First published online 12 May 2014.
}

communities (known locally as zacatonales) characterized mainly by Muhlenbergia spp., Festuca spp. and Jarava ichu and associated with trees of the genera Pinus, Alnus and Quercus (Hoth et al., 1987; Velázquez, 1993). The species' habitat has been destroyed gradually for agriculture, ranching and logging and by forest fires (Portales et al., 1997). Populations of the volcano rabbit are now at risk and this species is categorized as Endangered, both by the Mexican government (SEMARNAT, 2010) and on the IUCN Red List (AMCELA et al., 2008).

The habitat of a species can be examined at various scales, ranging from the local microscale (microhabitat) to the regional and global macroscales (Partridge, 1978; Delcourt \& Delcourt, 1988; Dunning et al., 1992; Morrison et al., 2006). Heterogeneous landscapes are a common feature in the geographical distribution of most species of mammals, even those with a restricted distribution (Feldhammer et al., 2007). This mosaic of environmental conditions or habitat types is necessary to meet all of the requirements for species survival (Hansson, 1979). At the local scale habitat use can be studied by measuring the population density or abundance of focal species, assuming that the abundance of animals is higher in habitats that are more suitable for sustaining populations (Partridge, 1978; Duncan et al., 1997). This suggests a unimodal distribution of population density along a gradient of habitat types (Velázquez, 1993).

Although the current status of wild populations of $R$. diazi is critical, until now no information has been reported on their size, structure or demography, and knowledge of the ecological relationships between this species and its habitat is scant. The available information on habitat use is limited to the landscape scale (Velázquez, 1993; Velázquez \& Heil, 1996). The only study carried out on the local scale was limited to the area of the Pelado volcano (Fa et al., 1992). Therefore little is known about the habitat relationships of this species at local scales or about its peripheral populations (Velázquez et al., 1996).

Here we evaluate habitat characteristics and their relationship to the abundance of the volcano rabbit, and generate a habitat quality index based on this relationship. We counted rabbit latrines as an indirect method of determining population abundance (Palomares, 2001). 


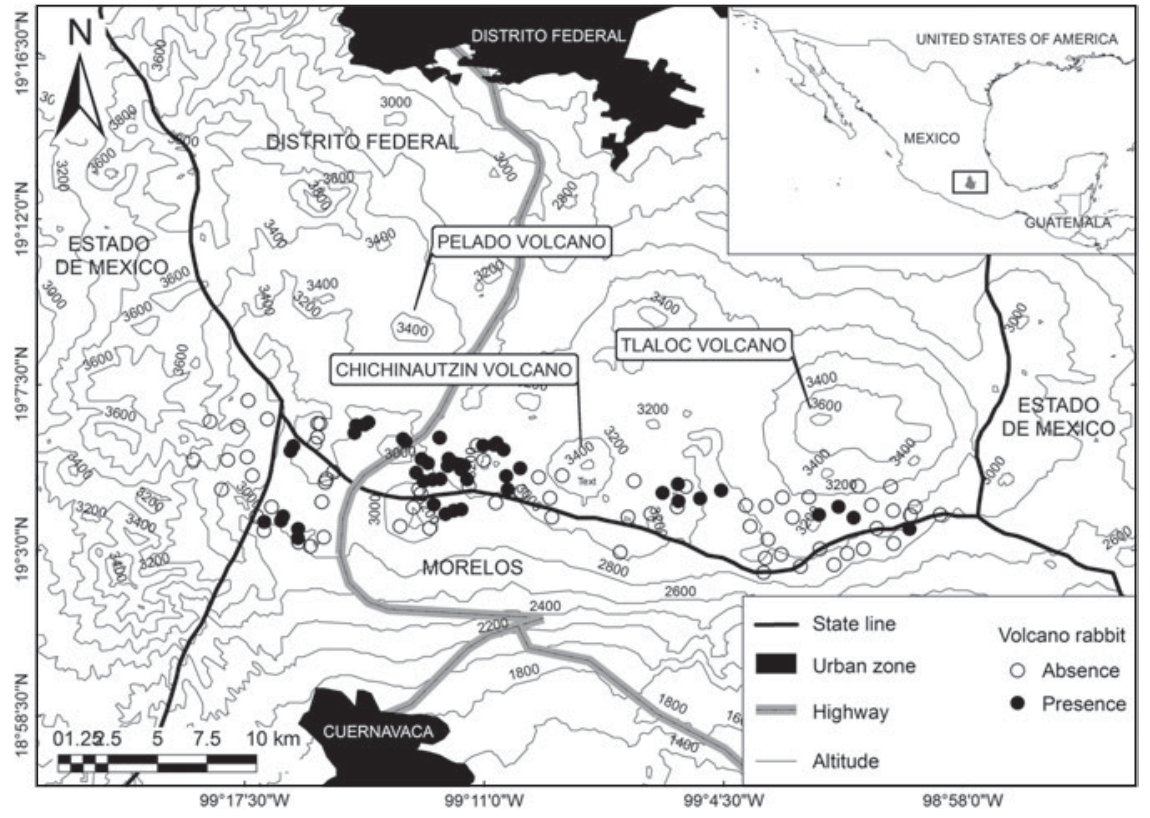

FIg. 1 Map of the Sierra Chichinautzin mountain range, with the locations of the 115 sampling sites. The rectangle on the inset shows the location of the main map in Mexico.

\section{Study area}

We investigated populations of the volcano rabbit in the Sierra Chichinautzin mountain range (Fig. 1). This is an important area because the populations here may be effectively isolated from other populations of the species that inhabit the Pelado, Tláloc, Popocatépetl and Iztaccíhuatl volcanoes, which are considered to be its core distribution areas (Velázquez et al., 1996). Part of the study area includes a protected area, the Chichinautzin Biological Corridor, which is located in the north-west of the state of Morelos, on the southern edge of the Federal District (Mexico City).

\section{Methods}

Using 1:20,000 aerial photographs from 1995 (National Institute of Statistics, Geography and Informatics, INEGI), we selected 115 sampling points at random above 2,800 m altitude (using contour lines at the 1:50,000 scale). We excluded urban areas (Tres Marías, Huitzilac, Coajomulco, Fierro del Toro and Parres). We visited all the sampling points to document habitat availability based on the presence of the grasses Muhlenbergia spp. and J. ichu. Sixty-four points had suitable habitat for $R$. diazi and 51 points did not (i.e. sites with fir, oak and pine forest, secondary vegetation, and deforested areas used mainly for growing oats and potatoes).

During June-December 2008 we estimated the abundance of the volcano rabbit at the sampling sites by counting the number of latrines. Following the method of Velázquez (1994) a group of 30 or more pellets was defined as a latrine. This method is considered reliable for estimating the population abundance of lagomorphs (Palomares, 2001) and has been used to estimate the population abundance of the volcano rabbit elsewhere in its range (Velázquez, 1994). At each of the 64 sampling sites we surveyed one $50 \times 50 \mathrm{~m}$ quadrat ( $0.25 \mathrm{ha}$ ) for fresh latrines.

We selected at random 22 of the 64 sampling points to describe the structure of the volcano rabbit's habitat. We measured seven vegetation attributes: tree height, cover, and diameter at breast height; shrub height and cover; and grass height and cover. We calculated standard deviation for grass height, shrub height and tree height, and for diameter at breast height as a proxy for habitat complexity. We used a clinometer to measure tree height and a telescopic rod to measure shrub height, in metres to the nearest centimetre. To calculate tree and shrub cover we measured the crown diameter of all trees and shrubs in the quadrat, using an electronic distance measuring tool. From the diameter the circular area of cover was calculated for each tree and shrub and these values were used to calculate percentage cover. We measured the height of 10 individuals of the two most abundant species of bunchgrass (Muhlenbergia macroura and J. ichu) and the percentage cover was estimated visually by the same person for each quadrat, thereby minimizing inter-observer variation.

The variables used to describe a habitat are typically interdependent and cannot be analysed individually (Cooley \& Lohnes, 1971). Therefore we conducted a principal components analysis, which generates new axes from the linear combination of the original variables. The resulting principal components have the advantage of being orthogonal and are considered independent variables. For this analysis we used a correlation matrix because the habitat description variables differed in unit and scale (James \& McCulloch, 1990). We selected the principal components with the highest eigenvalues, the sum of which 
accounted for $90 \%$ of the variance. We used the principal components as new descriptive variables of the habitat to construct a habitat quality index. We formulated a set of 21 predictive models using different combinations of the major components, which we analysed using generalized linear models under a Poisson distribution. The independent variables were the principal components and the dependent variable was the abundance of the volcano rabbit (as indicated by the number of latrines recorded at each site). To select the best models we used the Akaike information criterion (Akaike, 1973). We ran the principal components analysis in Statistica v. 6.o (StatSoft, Tulsa, USA) and the habitat analyses in $R$ v. 2.14.1 and Biodiversity $R$ (R Development Core Team, 2012; Kindt \& Coe, 2005).

\section{Results}

The total area sampled was $160,000 \mathrm{~m}^{2}$. In the 64 quadrats found to have suitable habitat we counted 3,330 latrines. Twenty-seven (42\%) of the sites had 1-50 latrines, 12 (19\%) had 51-150 latrines and nine (14\%) had 151-300 latrines. No latrines were found at $16(25 \%)$ sites. The number of latrines varied across the altitudinal range of $2,760-3,760 \mathrm{~m}$. Sites with 1-50 latrines were more common at 2,960-3,050 m

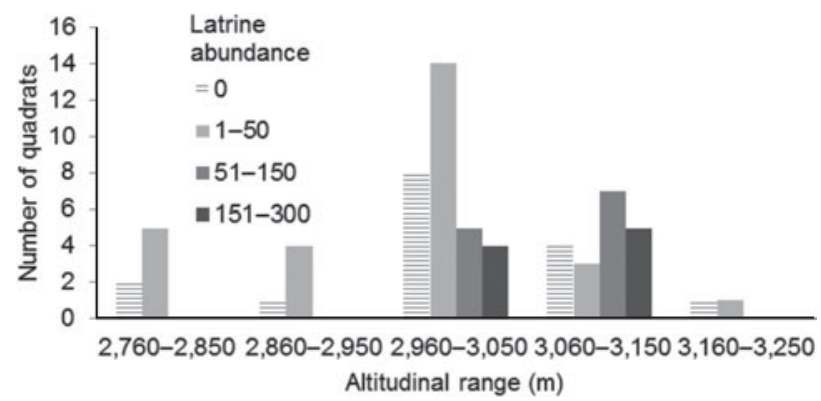

FIG. 2 Frequency distribution of latrine abundance with altitudinal range. and sites with 151-300 latrines were found at 3,060-3,150 m (Fig. 2).

Of the 22 sites selected for habitat characterization, eight (36\%) had 1-50 latrines, six (27\%) had 51-150 latrines, five (23\%) had 151-300 latrines and three (14\%) had no latrines.

We retained five principal components that together accounted for $90 \%$ of the total variance in the habitat data (Table 1). The first component (PC1) was negatively associated with tree layer (cover, diameter at breast height, and height). PC2 was negatively associated with shrub height and standard deviation of the shrub height. PC3 was associated with a mixture of variables from different strata: it was positively associated with grass height and tree height and negatively associated with the standard deviation of the height of tall shrubs. $\mathrm{PC}_{4}$ was positively associated with shrub coverage and $\mathrm{PC}_{5}$ was negatively associated with the standard deviation of grass height and positively associated with grass height.

Twenty-six different models were generated from combinations of the five principal components. The model with the lowest value for the Akaike information criterion held two major components ( $\mathrm{PC}_{3}$ and $\mathrm{PC}_{5}$; Table 2). This model represents the habitat quality index. Analysis of the correlations between the original variables and the principal components (Fig. 3) revealed that $R$. diazi tended to be more abundant at sites with taller grasses, a higher percentage of grass cover and taller trees, and where there was less variation in shrub and tree height.

\section{Discussion}

Our findings regarding the influence of the vegetation structure at a small scale ( $0.25 \mathrm{ha}$ ) on the distribution and abundance of the volcano rabbit in the Sierra Chichinautzin mountains broaden the understanding of the ecological relationships between this species and its habitat. A previous study of the relationship between the occurrence of the

TABLE 1 Weights of the habitat variables for each of the principal components and the percentage of the variance accounted for by each component. Significant correlations are in bold.

\begin{tabular}{|c|c|c|c|c|c|}
\hline Variable & $\begin{array}{l}\text { Principal } \\
\text { component } 1\end{array}$ & $\begin{array}{l}\text { Principal } \\
\text { component } 2\end{array}$ & $\begin{array}{l}\text { Principal } \\
\text { component } 3\end{array}$ & $\begin{array}{l}\text { Principal } \\
\text { component } 4\end{array}$ & $\begin{array}{l}\text { Principal } \\
\text { component } 5\end{array}$ \\
\hline Variance explained & 42.61 & 22.57 & 13.02 & 8.96 & 4.86 \\
\hline Grass coverage & 0.4816 & -0.5555 & 0.5712 & -0.2051 & 0.1736 \\
\hline Grass height & 0.5939 & -0.5216 & 0.3759 & -0.0875 & 0.3534 \\
\hline SD of grass height & 0.5565 & -0.5798 & 0.0908 & -0.3352 & -0.4474 \\
\hline Shrub height & -0.4102 & -0.7279 & -0.3936 & 0.2072 & 0.1810 \\
\hline SD of shrub height & -0.3423 & -0.8132 & -0.4183 & 0.0191 & 0.0220 \\
\hline Shrub coverage & -0.2983 & -0.4082 & 0.3068 & 0.6882 & -0.2271 \\
\hline Tree coverage & -0.9018 & 0.0946 & 0.1760 & 0.0907 & 0.2403 \\
\hline Tree height & -0.8189 & 0.0528 & 0.5189 & -0.0149 & -0.0947 \\
\hline SD of tree height & -0.7856 & -0.4333 & -0.0613 & -0.1744 & -0.1535 \\
\hline Diameter at breast height & -0.8415 & 0.0701 & 0.3685 & -0.2559 & -0.0358 \\
\hline SD of diameter at breast height & -0.7807 & -0.0620 & -0.1454 & -0.4501 & 0.0538 \\
\hline
\end{tabular}


TABle 2 Parameters of the best model selected based on Akaike information criterion, with estimated value, standard error, Wald's statistic, and $\mathrm{P}$ value.

\begin{tabular}{lllll}
\hline \multicolumn{5}{l}{ Model parameters } \\
\cline { 2 - 5 } & $\begin{array}{l}\text { Estimated } \\
\text { value }\end{array}$ & $\begin{array}{l}\text { Standard } \\
\text { error }\end{array}$ & $\begin{array}{l}\text { Wald's } \\
\text { statistic }\end{array}$ & $\mathrm{P}$ \\
\hline Intercept & 1.545463 & 0.003697 & 737.7 & 0.04570 \\
PC 3 & 0.040936 & 0.003542 & 133.6 & 0.00000 \\
PC 5 & 0.03967 & 0.003671 & 3.6 & 0.01772 \\
\hline
\end{tabular}
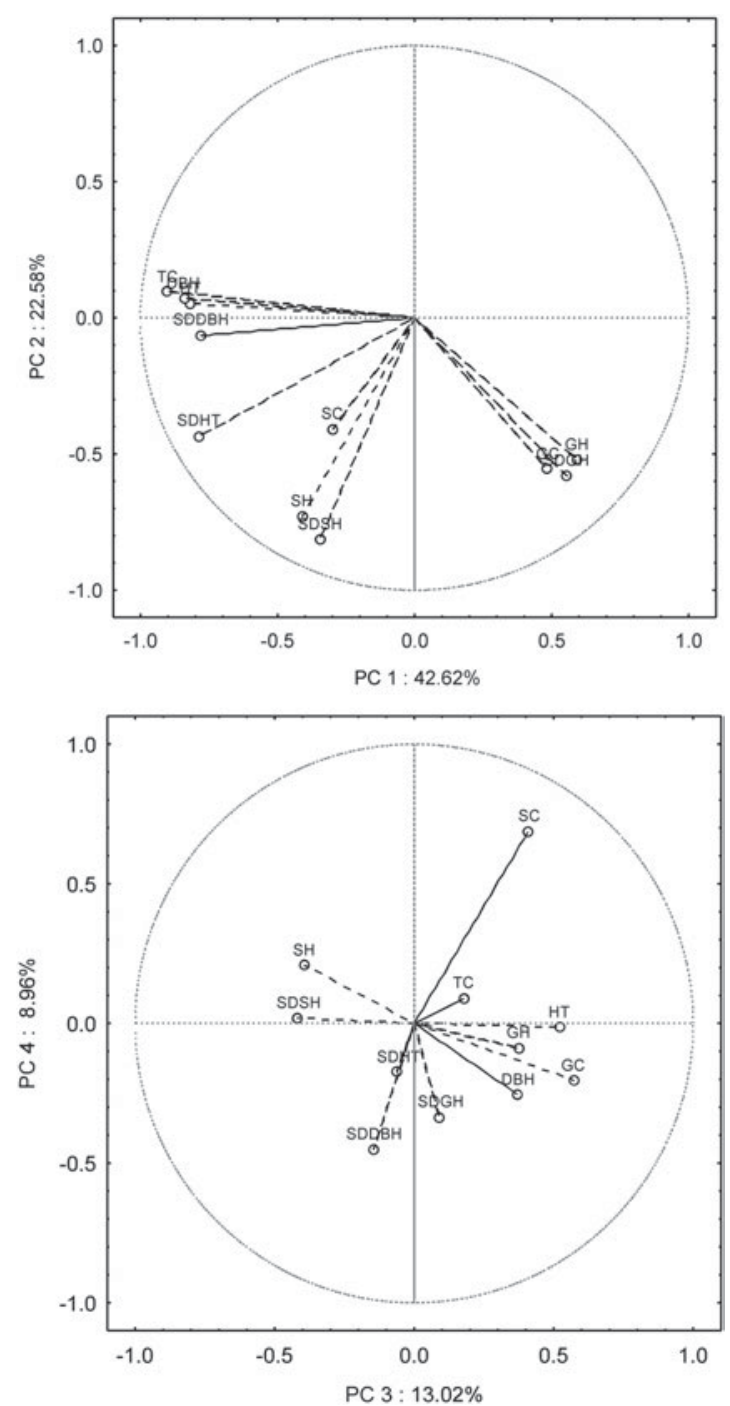

FIG. 3 The relative weights (correlations) of habitat variables with the four principal components. GC, grass cover; GH, grass height; SDGH, standard deviation of grass height; $\mathrm{SH}$, shrub height; SDSH, standard deviation of shrub height; SC, shrub cover; TC, tree cover; HT, tree height; SDHT, standard deviation of tree height; DBH, diameter at breast height; SDDBH, standard deviation of diameter at breast height.

volcano rabbit and its habitat (Velázquez \& Heil, 1996) focused on the floristic composition of vegetation and found that greater rabbit abundance was recorded in Festuca tolucensis and Trisetum altijugum-Festuca tolucensis communities. Based on that analysis Velázquez et al. (1996) further concluded that the volcano rabbit prefers a subalpine habitat. Studies of other animal species have indicated that it is the vegetation structure and landscape configuration rather than the floristic composition that determine patterns of habitat occupancy (Rotenberry, 1985; Rosenberg \& McKelvey, 1999; Pardini et al., 2005).

The availability of resources for feeding, breeding and shelter is a determining factor in the spatial distribution of the volcano rabbit, its habitat use and the shape of its home range (Gibb, 1993). It has also been shown that an animal's home range changes in response to its environment and that this response is directly related to habitat quality and resource distribution (Gibb, 1993; Hulbert et al., 1996; Lombardi et al., 2003; Stott, 2003; White et al., 2003).

Our findings that the presence and abundance of $R$. diazi are positively correlated with the height and cover of bunchgrass agree with those of another recent study (Hunter \& Cresswell, 2014). These habitat features are a source of protection and food for the volcano rabbit (Cervantes \& Martínez, 1992). The cover provided by grasses and the presence of a shrub layer may offer the volcano rabbit the best refuge from potential predators, including the bobcat Lynx rufus, the coyote Canis latrans, the long-tailed weasel Mustela frenata, the red-tailed hawk Buteo jamaicensis, the great horned owl Bubo virginianus and the rattlesnake Crotalus triseriatus (Cervantes-Reza, 1981).

The Sierra Chichinautzin may be the last core area of bunch grassland in central Mexico (Cabrera-García et al., 2006). However, this habitat is being degraded and destroyed by agricultural expansion, timber extraction and fire. This habitat loss is evidenced by the fact that only 64 of the 115 sampling sites in our survey were found to have suitable habitat for volcano rabbits.

The association between volcano rabbit abundance and the habitat quality index, together with the limited availability of suitable habitat documented in our field survey, suggests that populations of volcano rabbit in the study area are at risk of extinction. The species is a habitat specialist and therefore does not have the option of moving to a different type of habitat.

The data presented here, along with those previously reported for the landscape scale and for other areas of the species' range (Fa et al., 1992; Velázquez, 1993; Velázquez et al., 1996), can be used to inform strategies for the conservation of the volcano rabbit's habitat. The ongoing loss of suitable habitat for the species warrants the implementation of an environmental education programme and collaboration between academia, government and NGOs to ensure that the people of central Mexico receive benefits for conserving the habitat of this endemic, restricted-range species. 


\section{Acknowledgements}

We thank the laboratory group at the Facultad de Ciencias Biológicas of the Universidad Autónoma del Estado de Morelos for helping with the field work, and Bianca Delfosse for improving the English. This study was partially funded by the Comisión Nacional de Áreas Naturales Protegidas. Areli Rizo-Aguilar received a graduate studies scholarship from CONACYT (44564).

\section{References}

AKAIKE, H. (1973) Information theory as an extension of the maximum likelihood principle. In Second International Symposium on Information Theory (eds B.N. Petrov \& F. Csaki), pp. 267-281. Akademiai Kiado, Budapest, Hungary.

amCela (Mexican Association for Conservation and Study of Lagomorphs), Romero Malpica, F.J., Rangel Cordero, H., de Grammont, P.C. \& Cuarón, A.D. (2008) Romerolagus diazi. In IUCN Red List of Threatened Species v. 2013.1. Http://www.iucnredlist.org [accessed October 2013].

Cabrera-García, L., Velázquez, J.A. \& Escamilla, M.E. (2006) Identification of priority habitats for conservation of the Sierra Madre sparrow Xenospiza baileyi in Mexico. Oryx, 40, 211-217.

Cervantes, F.A. \& Martinez, J. (1992) Food habits of the rabbit Romerolagus diazi (Leporidae) in Central México. Journal of Mammalogy, 73, 830-834.

Cervantes-Reza, F. (1981) Some predators of the zacatuche (Romerolagus diazi). Journal of Mammalogy, 60, 850-851.

Cooley, W.W. \& Lohnes, P.R. (1971) Multivariate Data Analysis. J. Wiley and Sons, New York, USA.

Delcourt, H.R. \& Delcourt, P.A. (1988) Quaternary landscape ecology: relevant scales in space and time. Landscape Ecology, 2, 33-44.

Duncan, R.P., Colhoun, K.M. \& Foran, B.D. (1997) The distribution and abundance of Hieracium species (hawk weeds) in the dry grasslands of Canterbury and Otago. New Zealand Journal of Ecology, 21, 51-62.

Dunning, B.J., Danielson, B.J. \& Pullian, H.R. (1992) Ecological processes that affect populations in complex landscapes. Oikos, 65, $169-175$.

FA, J.E. \& Bell, D. (1990) The volcano rabbit Romerolagus diazi. In Rabbits, Hares and Pikas. Status Survey and Conservation Action Plan (eds J.A. Chapman \& J.E.C. Flux), pp. 143-146. IUCN/SSC Lagomorph Specialist Group, Oxford, UK.

Fa, J.E., Romero, F.J. \& López-Paniagua, J. (1992) Habitat use by parapatric rabbits in a Mexican high-altitude grassland system. Journal of Applied Ecology, 29, 357-370.

Feldhammer, G.A., Drickamer, L.C., Vessey, S.H. \& Merritt, J.F. (2007) Mammalogy: Adaptation, Diversity and Ecology. Johns Hopkins University Press, Baltimore, USA.

GibB, J.A. (1993) Sociality, time and space in a sparse population of rabbits (Oryctolagus cuniculus). Journal of Zoology, 229, 581-607.

HANSSON, L. (1979) On the importance of landscape heterogeneity in northern regions for the breeding population densities of homeotherms: a general hypothesis. Oikos, 33, 182-189.

Hoth, J., Velázquez, A., Romero, F.J., Leon, L., Aranda, M. \& BeLL, D.J. (1987) The volcano rabbit-a shrinking distribution and a threatened habitat. Oryx, 21, 85-91.
Hulbert, I.A.R., Glenn, R.I., Elston, D.A. \& Racey, P.A. (1996) Home-range sizes in a stratified upland landscape of two lagomorphs with different feeding strategies. Journal of Applied Ecology, 33, 1479-1488.

Hunter, M. \& Cresswell, W. (2014) Factors affecting the distribution and abundance of the Endangered volcano rabbit Romerolagus diazi on the Iztaccihuatl volcano, Mexico. Oryx. Http://dx.doi.org/10.1017/So030605313000525

James, F.C. \& McCulloch, C.E. (1990) Multivariate analysis in ecology and systematics: panacea or Pandora's box? Annual Review of Ecology and Systematics, 21, 129-166.

Kindt, R. \& Coe, R. (2005) Tree Diversity Analysis. A Manual and Software for Common Statistical Methods for Ecological and Biodiversity Studies. World Agroforestry Centre, Nairobi, Kenya.

Lombardi, L., Fernández, N., Moreno, S. \& Villafuerte, R. (2003) Habitat-related differences in rabbit (Oryctolagus cuniculus) abundance, distribution, and activity. Journal of Mammalogy, 84, 26-36.

Morrison, M.L., Marcot, B.G. \& Mannan, R.W. (eds) (2006) Wildlife-Habitat Relationships: Concepts and Applications. Island Press, Washington, DC, USA.

Palomares, F. (2001) Comparison of 3 methods to estimate rabbit abundance in a Mediterranean environment. Wildlife Society Bulletin, 29, 578-585.

Pardini, R., De Souza, S.M., Braga-Neto, R. \& Metzger, J.P. (2005) The role of forest structure, fragment size and corridors in maintaining small mammal abundance and diversity in an Atlantic forest landscape. Biological Conservation, 124, 253-266.

Partridge, L. (1978) Habitat selection. In Behavioural Ecology (eds J. R. Krebs \& N. B. Devie), pp. 351-376. Sinauer, Sunderland, USA.

Portales, G.L., Reyes, P., Rangel, H., Velázquez, A., Miller, P., Ellis, S. \& S Mith, A.T. (eds) (1997) International Workshop for the Conservation of Endangered Mexican Lagomorphs. IUCN/SSC Lagomorph Specialist Group and IUCN/SSC Conservation Breeding Specialist Group, Apple Valley, USA.

R Development Core Team (2012) R: A Language and Environment for Statistical Computing. R Foundation for Statistical Computing, Vienna, Austria.

Rosenberg, D.K. \& McKelvey, K.S. (1999) Estimation of habitat selection for central-place foraging animals. The Journal of Wildlife Management, 63, 1028-1038.

Rotenberry, J.T. (1985) The role of habitat in avian community composition: physiognomy or floristics? Oecologia, $67,213-217$

Semarnat (Secretaría de Medio Ambiente y Recursos Naturales) (2010) Norma Oficial Mexicana NOM-059SEMARNAT-2010. Protección Ambiental-Especies Nativas de México de Flora y Fauna Silvestre-Categorías de riesgo y especificaciones para su inclusión, exclusión o cambio-Lista de especies en riesgo. Diario Oficial de la Federación. Secretaría de Gobernación, Federal District, Mexico.

Sтотт, P. (2003) Use of space by sympatric European hares (Lepus europaeus) and European rabbits (Oryctolagus cuniculus) in Australia. Mammalian Biology, 68, 317-327.

Velázquez, A. (1993) Landscape Ecology of Tláloc and Pelado Volcanoes, Mexico. International Institute for Aerospace Survey and Earth Sciences, Enschede, The Netherlands.

Velázquez, A. (1994) Distribution and population size of Romerolagus diazi on El Pelado Volcano, Mexico. Journal of Mammalogy, 75, 743-749. 
Velázquez, A. \& Heil, G.W. (1996) Habitat suitability study for the conservation of the volcano rabbit (Romerolagus diazi). Journal of Applied Ecology, 33, 543-554.

Velázquez, A., Romero, F.J. \& León, L. (1996) Fragmentación del hábitat del conejo zacatuche. In Ecología y Conservación del Conejo Zacatuche (Romerolagus diazi) y su Hábitat (eds A. Velázquez, F. Romero \& J. López Paniagua), pp. 61-74. Universidad Nacional Autónoma de México y Fondo de Cultura Económica, Federal District, Mexico.

White, P.C.L., Newton-Cross, G., Gray, M., Ashford, R., White, C., \& SAunders, G. (2003) Spatial interactions and habitat use of rabbits on pasture and implications for the spread of the rabbit haemorrhagic disease in New South Wales. Wildlife Research, $30,49-58$

\section{Biographical sketches}

Areli Rizo-Aguilar is interested in the conservation biology of vertebrates and has been monitoring populations and habitat of the volcano rabbit. José Antonio Guerrero is working on the molecular systematics of bats and rodents and is also interested in the conservation and management of the volcano rabbit and its habitat. Mircea Hidalgo-Mihart has worked on the conservation and management of tropical mammals, especially carnivores and rodents, in western and south-eastern Mexico since 1998. Alberto GONZÁLEZ-ROMERO has been monitoring mammal populations in the Mapimi Biosphere Reserve in Durango, Mexico, and has also been studying the endemic ground squirrel of Perote. 